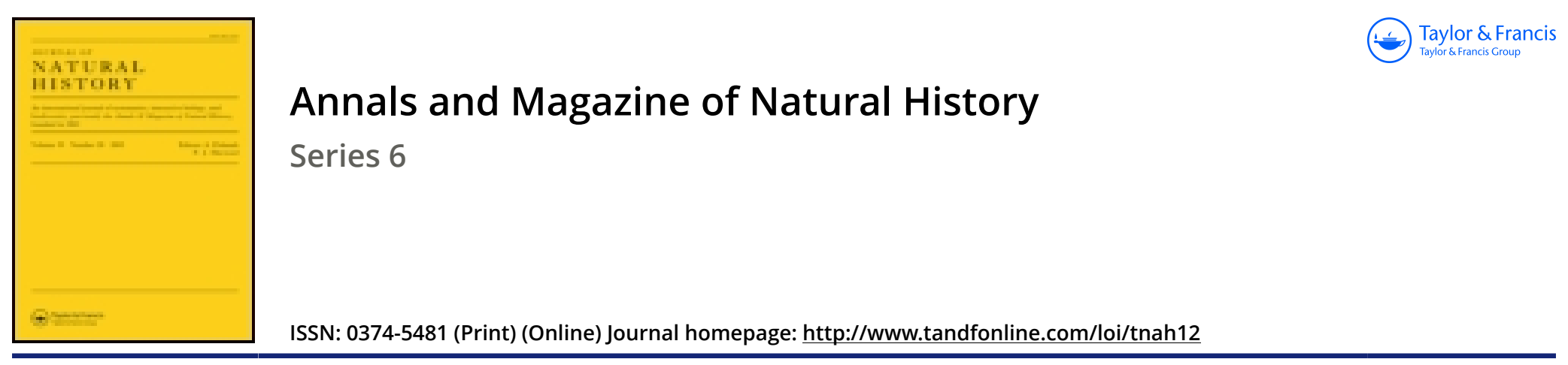

\title{
Holothuria nigra, Gray, and its synonymy
}

\section{Rev. Canon A.M. Norman M.A. D.C.L. F.R.S.}

To cite this article: Rev. Canon A.M. Norman M.A. D.C.L. F.R.S. (1893) Holothuria nigra, Gray, and its synonymy , Annals and Magazine of Natural History, 12:71, 409-411, DOI: 10.1080/00222939308677642

To link to this article: http://dx.doi.org/10.1080/00222939308677642

\section{Published online: 06 Oct 2009.}

Submit your article to this journal

Џلl Article views: 4

Q View related articles $\sqsubset$ 


\section{MISCELLANEOUS.}

Holothuria nigra, Gray, and its Synonymy.

By the Rev. Canon A. M. Norman, M.A., D.C.L., F.R.S., \&c.

\section{The Name.}

This species has been commonly styled in Britain "Holothuria nigra, Couch.” Prof. Jeffrey Bell (in Proc. Zool. Soc. 1884, p. 373) says the first use he can find of the name "Cucumaria nigra, Couch," is by Prof. Kinahan (Nat. Hist. Rev. vol. vi., 1859, p. 369), and that he has sought in vain for the use of any such title by Couch himself, and, unable to fathom the mystery, in Cat. Echin. Brit. Mus. (1892) he gives it as Holothuria nigra, auct. Curiously enough the solution is to be found in a previous B. M. Catalogue of Echinodermata.

The use of "Holothuria nigra, Couch," seems to have arisen out of two mistakes. The specific name originally appeared in J. E. Gray's List Brit. Anim. in Coll. B. M., Radiated Animals, 1848, p. 8, where will be found this entry-

\section{"Holothuria nigra.}

"Nigger or Cotton Spinner, Couch, Ann, \& Mag. N. H. xv. 171. t. 14.

"Inhab. Cornwall."

Mistake 1.-Gray, by a lapsus pennce, assigned to the authorship of Couch a paper which had been written by Peach.

Mistake 2.--Anthors reading the above entry supposed the specific name to have been given by the writer of the paper referred to, and thus wrote "Holothuria nigra, Couch," instead of, as it should have been, "Holothuria nigra, Gray." Peach had given no scientific title to his "Nigger."

\section{The Synonymy.}

Dr. von Marenzeller, in the paper translated in the 'Annals' of this month, makes Holothuria nigra a synonym of $H$. catanensis, Grube, and the latter a synonym of $H$. Forskalii, Delle Chiaje.

He states he arrived at this conclusion from the examination of Bell's figures of $H$. nigra and of a mounting of the spicula of which he had received from myself. Years ago I arrived at a similar conclusion by the comparison of two specimens of $H$. catanensis, which my friend Dr. von Marenzeller sent me, with our British species. On that point, then, we are perfectly agreed. On the high authority of Ludvig and Marenzeller I rely that it is also H. Forskahli, Delle Chiaje. The descriptions of the author of the species do not materially help me, and I have not Forskahl's work to refer to. 
But not only had I found our British species to be the same as $H$. catanensis, Grube, but that the Holothurians sent out from the Zool. Stat. Naples as "Holothuria Poli" are also referable to the species we are considering. Is, then, $H . P_{0} l i=H$. catanensis? - that is a question which has exercised me for a long time. Delle Chiaje's figure of $H$. Poli (Anim. s. Vert. Napoli, pl, vi. fig. 1 : reproduced in Anim. Invert. Sic. Cit. pl. cx. fig. 1) seems to be a good representation of $H$. catanensis, This species sent out as $H$. Poli is evidently common at Naples, and, if not rightly named, how is it that $H$. Poli has not been found, and how comes it that $H$. Forshahli, of which Delle Chiaje writes " $\mathrm{Ob}$ ejusdem raritatem viscera haud examinare potui," is common at Naples? Am I to conclude that Forshahli has become common and Poli disappeared, or are they one species? Theel, in the 'Challenger' Report on Holothuroidea, part ii. 1886 , p. 223, is completely puzzled about $H$. Poli.

Will Dr, ron Marenzeller or some other authority clear up this matter by giving us good illustrations of the spicules of the hody, papilla, pedicels, and tentacles of $H$. Poli? for by their spicula are the Holothurians most easily distinguished.

The question is, who is right as to the identification of $H$. Poli, the Zool. Stat. or cortain authors ?-for example, the descriptions of Theel just referred to, the figures by Sars of the spicules (Bidr. til Kunds. Middelharets Littoral-Fauna, 1857, figs. 75-77), which he called $H$. tubulosa, but Ludvig and Marenzeller refer to $H$. Poli, and those of. Selenka (Beit. z. Anat. u. System. der Holothurien, 1867, pl. xviii. figs. 44-46). These figures represent "buttons" (Theel); there are no buttons in $H$. Poli as identified at Naples. I do not see why Sars's figures should not have been drawn from "buttons" of $H$. tubulosa (fig. 77 being characteristic) and those of Selenka from $H$. Stellati. Leaving, then, this question of $H$. Poli as one of acknowledged doubt and ignorance on my part, we have-

Holothuria Forskahli, Delle Ch., 1823,=Nigger or Cotton Spinner, Peach, 1845,= Holothuria nigra, Gray, 1848,=Cucumaria nigra, "Couch," Kinahan, 1859, = Holothuria catanensis, Grube, $1864,=$ Stichopus Selenka, Th. Barrois, 1882, = Holothuria Forskalii*, Marenzeller, 1893.

I have specimens in my collection from Polperro, Cornwall (Laughrin); Valentia, Ireland (A. M. N., 1870); Plymouth (Marine Biol. Lab.); Naples (Zool. Stat., as "H. Poli"); Lesina (Marenzeller, as " $H$. catanensis") ; Fosse de Cap Breton, Bay of Biscay (A. M. N., 1880).

* As regards the spelling of this name, we may choose from $H$. Forskaoli, Chiaje, 1823, H. Forskahii, Chiaje, 1841, H. tubulosa, var. Forskali, Lamarck, $1840,=H$. Forskalii, Selenka, Ludvig, and Marenzeller. The spelling I have adopted is the name as corrected by Chiaje, and is in accordunce with the rules of nomenclature. 
Spicultr.-The characteristic spicule is that figurod by Grube ('Die Insel Lussin und ihre Meeresfauna,' 1864, fig. 7 a) and Jeffrey Bell (Cat. Echin. pl. vi. fig. to left and more magnified above), usually with four foramina and some nodules on the surface and edge; they may be regarded, as Theel observes, as imperfect "tables," the legs being undeveloped-but rarely the foramina are more numerous and the legs are in some measure developed. This characteristic spicule is sparingly scattered over the dermis.

Ventral pedicels. - The stem with no other spicules than of the characteristic form, but the disk capped with a large cribriform plate (the foramina of which are not arranged in any regular order); round the base of this terminal plate the pedicel is surrounded with a circlet of elongated spicula, with foramina more or less dereloped in a row on each side of the central axis (figured by Bell, fig. 5, to right).

Dorsal papille are white with a black tip. Some little distance beneath the dermis is a hollow coil composed of slightly curved rodlike spicules, which in their central portion are smooth and round in section and have their ends expanded and commonly rounded, piereed either with a few foramina or nodulous. Orerlying this coil are spicules of the characteristic type, but mixed here with others of a modified and larger size, having eight or even more foramina, the additional foramina having been built on to the sides of the original spicule after the usual manner of spicule growth.

Tentacles invested with spicules which are large towards the base and gradnally smaller distally, to correspond with the lessened size of the ramification of the tentacle; spicules arcuate or, more rarely, straight rods, their central portion roughened with a fow nodules or blunted spines, the extremities attenuated, rugose with crowded little nodulous points; occasionally at the extremity and sometimes on central portion minute foramina are to be seen; such perforated spicules are somewhat flattened instead of round in section.

Marenzeller is mistaken in supposing that this species does not attain so large a size in the Atlantic as in the Mediterranean. Some beautifully preserved specimens sent to me from the Plymouth Laboratory measure over 8 inches in length.

The total absence of the oval spicules which Theel calls "buttons" at once distinguishes this species from $H$. tubulosa, $H$. Stellati, $H$. Sanctori, H. Helleri, and H. impatiens of the Mediterranean, with all of which I have compared it; while the absence of the fine "tables" of the northern $H$. tremula and $H$. intestinalis makes it impossible to confound it with those species. 